\title{
ANALISIS PERUBAHAN CADANGAN HARA PADA BERBAGAI PENGGUNAAN LAHAN DAN KELERENGAN DI DAS MIKRO KALI KUNGKUK, KOTA BATU
}

\section{Analysis of Changes in Nutrient Reserves at Various Land Uses and Slopes in The Kali Kungkuk Micro Watershed, Batu City}

\author{
Refki Aulia Wiwaha, Syahrul Kurniawan* \\ Jurusan Tanah, Fakultas Pertanian, Universitas Brawijaya, Jl. Veteran 1 Malang, 65145 \\ *Penulis korespondensi: syahrul.fp@ub.ac.id
}

\begin{abstract}
The Kali Kungkuk micro watershed which is located in the upper area of Brantas watershed, had experienced forest conversion to horticulture during the last fourth decades. Since the physiographic of Kali Kungkuk micro watershed is hilly, forest conversion to horticulture may result in soil nutrient stock changes. The research aimed to analyze soil nutrient stock from forest to horticulture land uses (i.e. apple orchard and vegetables) in the Kali Kungkuk micro watershed. The field research was conducted on three different land uses (i.e. vegetable land (PK), apple orchard (PA), and forest (PH)) and four land slope classes (i.e. slope $0-8 \%$ (K1), $8-15 \%(\mathrm{~K} 2), 15-25 \%(\mathrm{~K} 3)$, and $>25 \%(\mathrm{~K} 4)$ ), with three, replicates plots of each. Soil samples were collected at three different depths (0-10, 10-30, and $30-50 \mathrm{~cm}$ ) from each plot. The parameters measured included soil texture, bulk density, standing litter mass, canopy cover, basal area, soil organic carbon and total nitrogen. Data analysis was conducted with Linear Mixed Effect Models with a level of 5\% and a further analysis of LSD test level of $5 \%$ as well as a correlation test between observational parameters. The results showed that differences in land use and slope affected to significant differences in the content of soil organic $\mathrm{C}$ and total $\mathrm{N}$. In general, forests had higher soil $\mathrm{C}$ and $\mathrm{N}$ stocks as compared to other land uses (i.e. apple orchard and vegetables). Furthermore, soil organic $\mathrm{C}$ and total $\mathrm{N}$ was higher in the low slopes (i.e. $0-8 \%)$ and $(8-15 \%)$ as compared to the high slopes (i.e. 15-25\%) and $(>25 \%$ ). The study found a positive correlation between soil nutrient stocks (i.e. $\mathrm{C}$ and $\mathrm{N}$ ) and clay content. In contrast, soil C and $\mathrm{N}$ stock was negatively correlated with soil bulk density. Soil fertility degradation that occurs in the Kali Kungkuk micro watershed (i.e. apple orchard and vegetables) requires serious attention in soil management in order to ensure the sustainability of apple and vegetable production.
\end{abstract}

Keywords : apple orchard, micro watershed, nutrient stocks, soil fertility management, vegetable land

\section{Pendahuluan}

Daerah Aliran Sungai (DAS) mikro Kali Kungkuk membentang luas dari Desa Sumber Brantas dan Tulungrejo yang masuk ke dalam wilayah Kecamatan Bumiaji Kota Batu dan sebagian kawasan hutan alami Tahura R. Soerjo. Sebagian besar wilayah DAS mikro Kali Kungkuk terletak di lereng pegunungan ArjunoWelirang pada ketinggian rata-rata 1.500 meter di atas permukaan laut (BPS, 2018). Kurang lebih $24 \%$ dari total kawasan Kecamatan
Bumiaji adalah kawasan pertanian. Kegiatan pertanian menjadi salah satu pilihan mata pencaharian masyarakat di DAS Mikro Kali Kungkuk. Temperatur udara yang berkisar 15$27^{\circ} \mathrm{C}$ menjadikan wilayah tersebut sesuai untuk tanaman hortikultura sehingga penggunaan lahan di DAS Mikro Kali Kungkuk didominasi oleh pertanian intensif. Namun, kegiatan pertanian intensif tanpa memperhatikan kaidahkaidah konservasi semakin meningkatkan permasalahan di DAS Mikro Kali Kungkuk, 


\section{Jurnal Tanah dan Sumberdaya Lahan Vol 8 No 1: 1-8, 2021 \\ e-ISSN:2549-9793, doi: 10.21776/ub.jts1.2021.008.1.1}

salah satunya berkaitan dengan degradasi kesuburan tanah. Hal tersebut ditunjukkan bahwa kegiatan pertanian semusim masih terdapat pada kelas 15-40\% yang mana hal tersebut tidak sesuai dengan kriteria dan tata cara yang ditetapkan dalam Penyusunan Pola Rencana Teknik Lapangan Rehabilitasi Lahan dan Konservasi Tanah yang disusun oleh Departemen Kehutanan pada tahun 2003.

Salah satu degradasi lahan yang terjadi pada kegiatan pertanian intensif di daerah berlereng adalah penurunan kesuburan tanah. Penurunan kesuburan tanah tersebut dapat mempengaruhi kemampuan tanah untuk menyediakan nutrisi bagi tanaman. Selain itu, degradasi lahan dapat memberikan dampak negatif yang lebih luas terhadap lingkungan, sosial dan ekonomi masyarakat sekitar. Simbolon et al. (2016) melaporkan bahwa penurunan kesuburan tanah menyebabkan penurunan produksi tanaman dan menambah biaya pembelian pupuk sehingga dapat menurunkan kesejahteraan petani.

Penelitian ini ditujukan untuk mengkaji pengaruh perbedaan kelerengan dan penggunaan lahan terhadap cadangan $\mathrm{C}$ dan $\mathrm{N}$. Penelitian ini diharapkan dapat memberikan informasi dasar dalam pemanfaatan lahan dengan faktor pembatas kelerengan guna mengoptimalkan produktivitas tanaman di DAS Mikro Kali Kungkuk.

\section{Bahan dan Metode}

Penelitian dilaksanakan di DAS Mikro Kali Kungkuk yang terletak di Kecamatan Bumiaji, terutama di Desa Tulungrejo dan Sumber Brantas mulai bulan Januari 2019 sampai dengan Juni 2020. Analisis tanah dilakukan di Laboratorium Jurusan Tanah Fakultas Pertanian, Universitas Brawijaya. Penelitian lapangan dilaksanakan di tiga penggunaan lahan yang berbeda yaitu lahan sayuran (PK), kebun apel (PA), dan hutan (PH). Pada penggunaan lahan sayuran dan kebun apel, penelitian dilakukan diempat kelas kelerengan lahan yaitu kelerengan 0-8\% (K1), kelerengan 8-15\% (K2), kelerengan 15-25\% (K3), dan kelerengan $>25 \%(\mathrm{~K} 4)$. Pada penggunaan lahan hutan (PH), penelitian lapangan dilakukan di 3 kelas kelerengan $(0-8 \%, 8-15 \%$, dan $>25 \%)$ dikarenakan kondisi di lapangan sulit menemukan lokasi hutan dengan kelerengan 15$25 \%$. Setiap kombinasi penggunaan lahan dan kelerengan dilakukan ulangan sebanyak 3 kali sehingga total plot pengamatan sebanyak 33 lokasi.

\section{Pengambilan sampel tanah}

Pengambilan sampel tanah dilakukan pada semua plot pengamatan yang telah ditentukan. Plot pewakil berukuran $20 \mathrm{~m}$ x $20 \mathrm{~m}$ dengan 3 sub plot pengamatan di dalamnya berukuran 5 $\mathrm{m}$ x $5 \mathrm{~m}$ yang ditentukan secara acak. Pengambilan sampel tanah dilakukan pada 3 kedalaman yaitu $0-10 \mathrm{~cm}, 10-30 \mathrm{~cm}$ dan $30-50$ $\mathrm{cm}$.

\section{Pengukuran luas bidang dasar (LBD) Pohon}

Pengukuran diameter pohon dilakukan dengan cara melilitkan meteran pada pohon setinggi 1,3 $\mathrm{m}$ dari permukaan tanah untuk mendapatkan nilai keliling batang. Kemudian nilai tersebut dikonversi menjadi diameter pohon yang dapat digunakan untuk menentukan Luas Bidang Dasar (LBD).

\section{Analisis laboratorium dan analisa data}

Analisis laboratorium dilakukan dengan mengkompositkan sampel tanah dari 3 sub plot pada setiap plot pengamatan. Analisis laboratorium meliputi pengukuran C-organik, N-total, Berat Isi, dan Tekstur). Cadangan unsur hara $\mathrm{C}$ dan $\mathrm{N}$ dihitung dengan rumus:

$$
\begin{array}{ll}
\text { Elemen stok }= & \% \mathrm{Ek}\left(\mathrm{g} \mathrm{kg}^{-1}\right) \times \mathrm{BI}(\mathrm{g} \\
\left(\mathrm{g} \mathrm{m}^{-2}\right) & \left.\mathrm{cm}^{-3}\right) \times \mathrm{KLO}(\mathrm{cm}) \times \\
& 10.000 \mathrm{~cm}^{2} \mathrm{~m}^{-2} \div 1000 \\
& \mathrm{~g} \mathrm{~kg}^{-1}
\end{array}
$$

Dimana Ek adalah konsentrasi elemen ( $\mathrm{C}$ atau $\mathrm{N})$, BI adalah berat isi tanah, KLO adalah kedalaman lapisan olah (Allen et al., 2016). Data yang diperoleh, ditabulasi, kemudian dilakukan uji normalitas (Shapiro-Wilk), kemudian dianalisis keragamannya dengan Analysis of $V$ ariance (ANOVA) taraf 5\% menggunakan program regresi untuk mengetahui pengaruh penggunaan lahan dan kelerengan terhadap parameter pengamatan. Untuk mempelajari hubungan antara $\mathrm{C}$ dan $\mathrm{N}$ dengan karakteristik lahan dan sifat fisika tanah (bobot isi dan partikel tanah) dilakukan uji korelasi. 


\section{Hasil dan Pembahasan}

\section{Karakteristik plot penelitian}

Hasil pengukuran karakteristik lahan pada berbagai penggunaan lahan dan kelerengan disajikan dalam (Tabel 1). Lahan hutan dengan populasi pohon yang lebih rendah dibandingkan dengan kebun apel, memiliki tutupan kanopi dan luas bidang dasar (LBD) yang lebih besar dibandingkan dengan kebun apel. Hal ini menunjukkan bahwa lahan hutan didominasi oleh pohon yang berukuran besar dengan kanopi yang rapat. Diantara penggunaan lahan hutan, hutan yang terletak di kelas kelerengan $>$ $25 \%$ memiliki tutupan dasar pohon (LBD) tertinggi diantara lahan hutan dengan kelas kelerengan $0-8 \%$ dan 8-15\%. Hal tersebut diduga disebabkan oleh lokasi yang curam sehingga sangat sedikit mengalami gangguan terutama oleh aktivitas manusia.

Tabel 1. Populasi pohon, kanopi, LBD, dan seresah.

\begin{tabular}{ccccc}
\hline Lokasi & $\begin{array}{c}\text { Populasi } \\
\left(\text { pohon } \mathbf{h a}^{-\mathbf{1}} \mathbf{)}\right.\end{array}$ & $\begin{array}{c}\text { Kanopi } \\
\mathbf{( \% )}\end{array}$ & $\begin{array}{c}\mathbf{L B D} \\
\left(\mathbf{c m}^{\mathbf{2}} \mathbf{m}^{-\mathbf{2}} \mathbf{)}\right.\end{array}$ & $\begin{array}{c}\text { Seresah } \\
\mathbf{( t ~ h a}^{-1} \mathbf{)}\end{array}$ \\
\hline PKK1 & - & - & - & - \\
PKK2 & - & - & - & - \\
PKK3 & - & - & - & - \\
PKK4 & - & - & - & - \\
PAK1 & 2.500 & 57,01 & 0,26 & 0,46 \\
PAK2 & 2.500 & 53,86 & 0,24 & 0,81 \\
PAK3 & 2.500 & 53,29 & 0,25 & 0,89 \\
PAK4 & 1.111 & 50,34 & 0,22 & 0,45 \\
PHK1 & 600 & 88,76 & 33,50 & 8,88 \\
PHK2 & 662 & 88,98 & 36,08 & 9,13 \\
PHK4 & 712 & 89,81 & 40,05 & 9,94 \\
\hline
\end{tabular}

Keterangan: PKK (lahan kentang); PAK (lahan apel); PHK (hutan)LBD (Luas Bidang Dasar).

Perbedaan usia dan kompleksitas tanaman mempengaruhi jumlah seresah dimana hutan memiliki jumlah seresah paling tinggi diantara penggunaan lahan lainnya. Menurut Bot dan Benittes (2005) jumlah seresah dipengaruhi oleh keadaan lingkungan, jenis tanaman, usia tanaman serta waktu.

\section{C-organik tanah dan C stock tanah}

Berdasarkan hasil pengukuran, perbedaan penggunaan lahan berpengaruh $(\mathrm{p}<0,05)$ terhadap konsentrasi C-organik dalam tanah pada berbagai kedalaman $(0-10,10-30$, dan 30$50 \mathrm{~cm}$ ). Secara umum nilai C-organik paling rendah berada pada lahan sayuran, dan Corganik paling tinggi terdapat pada lahan hutan (Tabel 2). Hal ini disebabkan karena lahan hutan mampu menyediakan bahan organik yang cukup terhadap lingkungannya, ditunjukkan oleh berat kering seresah di hutan yang lebih tinggi dibandingkan dengan penggunaan lahan lainnya (Tabel 1). Siklus hara tertutup pada lahan hutan juga tetap menjaga kondisi hara tetap berada pada ekosistemnya. Kompleksitas tanaman pada penggunaan lahan hutan juga mempengaruhi jumlah C-organik tanah. Banyaknya pohon berukuran besar di lahan hutan memberikan masukan C-organik secara terus-menerus. Sesuai dengan pendapat Bot dan Banites (2005) salah satu faktor yang mempengaruhi ketersediaan C-organik adalah vegetasi yang mana C-organik sangat dipengaruhi oleh kualitas dan kuantitas input bahan organik baik dari vegetasi dan pengelolaan lahan. Ditambahkan pula bahwa lahan hutan dengan vegetasi tanaman beragam dan kanopi lebar serta tanpa olah tanah mampu menyediakan Corganik lebih besar daripada lahan terbuka (Kempen et al., 2018). Pertanian tanpa olah tanah, aplikasi tanaman penutup, perbaikan manajemen nutrisi dan daur ulang residu tanaman seperti seresah sangat banyak direkomendasikan dalam meningkatkan ketersediaan C-organik dalam tanah (Pawlson $e t$ al., 2011). Selain penggunaan lahan, kandungan C organik tanah juga berbeda antar kelas 
kelerengan (Tabel 2). Nilai C-organik menurun selaras dengan kenaikan kelas lereng. Hal ini diduga akibat dari erosi tanah yang dapat membawa partikel-partikel tanah yang kaya akan bahan organik berpindah menuju bagian yang lebih rendah (lembah). Sesuai dengan pendapat Bot dan Banites (2005) salah satu faktor yang mempengaruhi ketersediaan C-organik adalah topografi, dimana akumulasi bahan organik cenderung berada di bagian bawah bukit akibat dari proses pengangkutan dari lereng-lereng. Menurut Singh dan Benbi (2018) tingkat dan besaran ketersediaan C-organik dalam tanah dipengaruhi beberapa faktor diantaranya sifat tanah, kondisi iklim, dan penggunaan lahan. Sejumlah penelitian terkait manajemen penggunaan lahan termasuk intensifikasi pertanian, pertanian tanpa olah tanah, aplikasi tanaman penutup, perbaikan manajemen nutrisi dan daur ulang residu tanaman seperti seresah sangat banyak direkomendasikan dalam meningkatkan ketersediaan C-organik dalam tanah (Pawlson et al., 2011). Hasil penghitungan cadangan $\mathrm{C}$ tanah pada berbagai penggunaan lahan dan kelerengan didapati bahwa nilai cadangan C- tanah tertinggi terdapat pada lahan hutan dengan kelas kelerengan $0-8 \%$, yaitu sebesar $131 \mathrm{t} \mathrm{ha}^{-1}$ dan nilai terendah pada lahan apel dengan kelerengan $>25 \%$, sebesar $84,8 \mathrm{t}$ ha-1 (Gambar 1)

Tabel 2. C-organik pada berbagai penggunaan lahan dan kelerengan.

\begin{tabular}{cccc}
\hline \multirow{2}{*}{$\begin{array}{c}\text { Penggunaan } \\
\text { Lahan }\end{array}$} & \multicolumn{3}{c}{ C-organik (\%) } \\
\cline { 2 - 4 } & $0-10$ & $10-30$ & $30-50$ \\
\cline { 2 - 4 } & $2,40 \mathrm{~b}$ & $2,04 \mathrm{~b}$ & $1,61 \mathrm{~b}$ \\
PK & $3,01 \mathrm{~b}$ & $2,57 \mathrm{~b}$ & $2,01 \mathrm{~b}$ \\
PA & $5,40 \mathrm{a}$ & $3,75 \mathrm{a}$ & $2,80 \mathrm{a}$ \\
PH & & & \\
\hline Kelerengan & & & \\
\hline K1 & $4,16 \mathrm{a}$ & $3,09 \mathrm{a}$ & $2,74 \mathrm{a}$ \\
K2 & $4,01 \mathrm{a}$ & $3,18 \mathrm{a}$ & $2,21 \mathrm{ab}$ \\
K3 & $2,61 \mathrm{~b}$ & $2,22 \mathrm{~b}$ & $1,62 \mathrm{~b}$ \\
K4 & $2,70 \mathrm{~b}$ & $2,15 \mathrm{~b}$ & $1,59 \mathrm{~b}$ \\
\hline
\end{tabular}

Keterangan: $\mathrm{PK}=$ lahan sayur, $\mathrm{PA}=$ kebun apel, $\mathrm{PH}$ $=$ hutan. $\mathrm{K} 1=$ kelerengan $0-8 \%, \mathrm{~K} 2=$ kelerengan 8 $15 \%, \mathrm{~K} 3=$ kelerengan $15-25 \%, \mathrm{~K} 4=$ kelerengan $>25 \%$. Angka yang diikuti huruf yang berbeda pada kolom yang sama adalah beda nyata pada uji BNT $5 \%$.

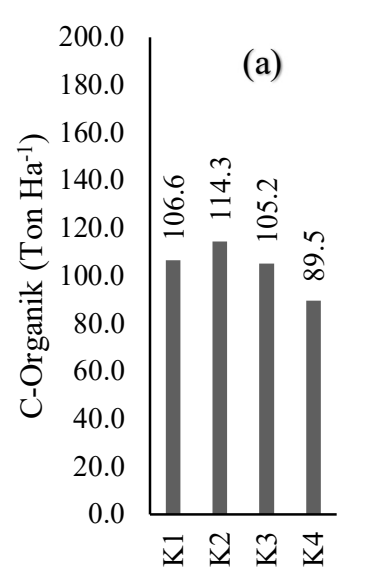

Kelerengan (\%)

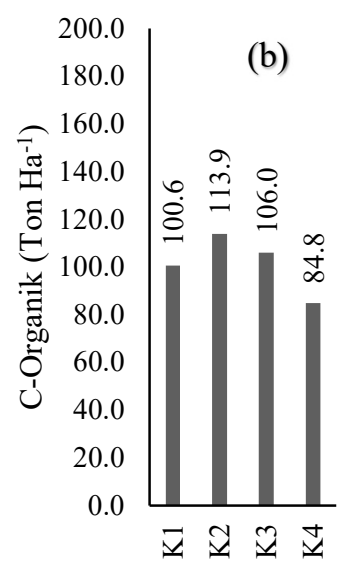

Kelerengan (\%)

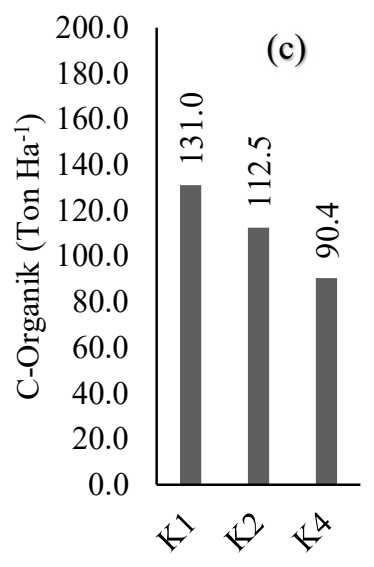

Kelerengan (\%)

Gambar 1. Cadangan C tanah: (a) kentang; (b) Apel; (c) Hutan.

Keterangan :Kriteria angka yang diikuti dengan huruf yang berbeda pada kolom yang sama menyatakan beda nyata pada uji BNT 5\%.

Tingginya cadangan C pada lahan hutan disebabkan oleh banyaknya jenis tanaman dan ragam kualitas seresah. Menurut Baker et al. (2006), pada kebanyakan tanaman sebanyak 30-
$50 \%$ dari karbon yang terfiksasi dalam fotosintesis pada awalnya dipindahkan ke bawah permukaan tanah yang digunakan beberapa bagian untuk pertumbuhan struktur dari sistem 


\section{Jurnal Tanah dan Sumberdaya Lahan Vol 8 No 1: 1-8, 2021 e-ISSN:2549-9793, doi: 10.21776/ub.jts1.2021.008.1.1}

akar, respirasi tanaman (autrophic), dan beberapa bagian hilang ke dalam tanah sekitar dalam bentuk organik (rbizodeposition), dipisahkan dalam bentuk jaringan mati dari jaringan hidup selama ekspansi akar maupun diekskresikan dalam berbagai senyawa. Selanjutnya, karbon ditahan di dalam tanah dalam bentuk residu yang perlahan menyatu ke dalam agregat tanah (McKenzie, 2010). Akibatnya, agregat tanah menjadi lebih kaya bahan organik yang nantinya akan membantu menjadi situs pertukaran hara.

\section{N-total dan N stock tanah}

Berdasarkan hasil analisa statistik menunjukkan bahwa penggunaan lahan memiliki pengaruh nyata terhadap konsentrasi nitrogen $(\mathrm{N})$ total dalam tanah pada berbagai kedalaman $(\mathrm{p}<$ $0,05)$. Konsentrasi $\mathrm{N}$-total terbanyak berada pada lahan hutan dan paling sedikit terdapat pada lahan sayuran (Tabel 3). Beberapa faktor yang diduga menyebabkan tingginya $\mathrm{N}$ total tanah di lahan hutan adalah: 1) tingginya masukan seresah yang menjadi sumber utama $\mathrm{N}$ di dalam tanah, dan 2) rendahnya kehilangan $\mathrm{N}$ akibat pencucian / erosi / volatilisasi. Akumulasi bahan organik tanah mampu meningkatkan mineralisasi dan ketersediaan Nitrogen dalam tanah (Doetterl et al., 2016). Di sisi lain, besarnya erosi dan perkolasi yang kemungkinan terjadi di lahan sayuran dan kebun apel berpotensi besar di dalam menyebabkan kehilangan $\mathrm{N}$ tanah. Selain itu penggunaan lahan secara intensif sepanjang tahun dapat meningkatkan kerusakan lahan tersebut baik secara fisik maupun kimia. Selain penggunaan lahan, hasil analisis sidik ragam juga menunjukkan bahwa perbedaan kelerengan memberikan pengaruh nyata terhadap konsentrasi $\mathrm{N}$-total dalam tanah $(\mathrm{p}<0,05)$. Konsentrasi nitrogen menurun seiring kenaikan kelas lereng (Tabel 3). Hal ini sebagian besar disebabkan oleh sifat nitrogen sendiri yang aktif bergerak sehingga dapat dengan mudah terbawa oleh limpasan permukaan maupun tercuci ke lapisan yang lebih dalam. Limpasan permukaan tersebut dapat mengalir ke bagian lereng menuju bagian yang lebih rendah yaitu lembah sehingga menyebabkan bagian lereng menjadi lebih miskin akan. Basic et al. (2004) menyatakan bahwa erosi akibat pengolahan tanah pada lahan miring atau berlereng merupakan faktor utama dalam degradasi lahan di lereng. Secara keseluruhan cadangan $\mathrm{N}$ tanah pada kedalaman $0-50 \mathrm{~cm}$ di tiga penggunaan lahan dengan 4 kelas kelerengan yang berbeda yang ada di DAS mikro Kali Kungkuk Kota Batu berkisar antara 4.5 $20.6 \mathrm{t} \mathrm{ha}^{-1}$.

Tabel 3. N-total pada berbagai penggunaan lahan dan kelerengan.

\begin{tabular}{cccc}
\hline Penggunaan & \multicolumn{3}{c}{ N-total (\%) } \\
\cline { 2 - 4 } Lahan & \multicolumn{3}{c}{ Kedalaman $(\mathbf{c m})$} \\
\cline { 2 - 4 } & $0-10$ & $10-30$ & $30-50$ \\
\hline PK & $0,24 \mathrm{c}$ & $0,22 \mathrm{c}$ & $0,19 \mathrm{c}$ \\
PA & $0,51 \mathrm{~b}$ & $0,45 \mathrm{~b}$ & $0,38 \mathrm{~b}$ \\
PH & $0,73 \mathrm{a}$ & $0,61 \mathrm{a}$ & $0,51 \mathrm{a}$ \\
\hline Kelerengan & & & \\
\hline K1 & $0,59 \mathrm{~b}$ & $0,49 \mathrm{c}$ & $0,43 \mathrm{~b}$ \\
K2 & $0,54 \mathrm{~b}$ & $0,46 \mathrm{~b}$ & $0,38 \mathrm{~b}$ \\
K3 & $0,36 \mathrm{a}$ & $0,32 \mathrm{a}$ & $0,27 \mathrm{a}$ \\
K4 & $0,37 \mathrm{a}$ & $0,33 \mathrm{a}$ & $0,28 \mathrm{a}$ \\
\hline
\end{tabular}

Keterangan: $\mathrm{PK}=$ lahan sayur, $\mathrm{PA}=$ kebun apel, $\mathrm{PH}$ $=$ hutan. $\mathrm{K} 1=$ kelerengan $0-8 \%, \mathrm{~K} 2=$ kelerengan 8 $15 \%, \mathrm{~K} 3=$ kelerengan $15-25 \%, \mathrm{~K} 4=$ kelerengan $>25 \%$. Angka yang diikuti huruf yang berbeda pada kolom yang sama adalah beda nyata pada uji BNT $5 \%$.

Apabila dilihat lebih rinci terlihat pada lahan pertanian intensif yaitu pada lahan kentang dan apel kelerengan kelas 2 dan kelas 1 memiliki cadangan N-total yang lebih tinggi daripada kelas lereng 3 dan 4 (Gambar 2). Secara umum, Gambar 2 menunjukkan bahwa lahan kentang sudah banyak mengalami degradasi kesuburan tanah, ditunjukkan dari nilai cadangan $\mathrm{N}$-total tanah pada kedalaman 0-50 cm di lahan kentang hampir $50 \%$ dari cadangan $\mathrm{N}$-total di lahan hutan. Ini menunjukkan bahwa aplikasi pupuk $\mathrm{N}$ (baik anorganik maupun organik) di lahan kentang tidak cukup untuk menggantikan unsur $\mathrm{N}$ yang hilang bersama pengangkutan panen dan erosi serta volatilisasi. Selain itu, cara pemupukan nitrogen dengan cara ditabur di permukaan tanah menambah resiko kehilangan akibat penguapan. Penguapan tersebut menyebabkan N-total pada lahan kentang menjadi rendah. Sesuai pendapat Nainggolan $e t$ al. (2009) kehilangan nitrogen tanah dapat disebabkan oleh penguapan $\mathrm{N}$ melalui air kapiler dan penempatan pupuk yang kurang tepat di permukaan menyebabkan penguapan secara langsung. 


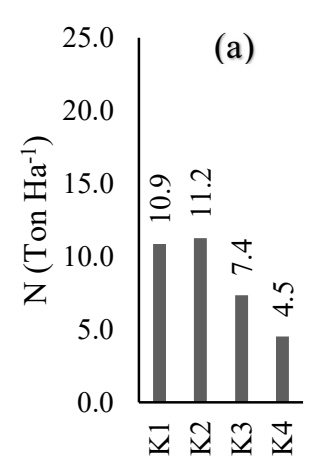

Kelerengan (\%)

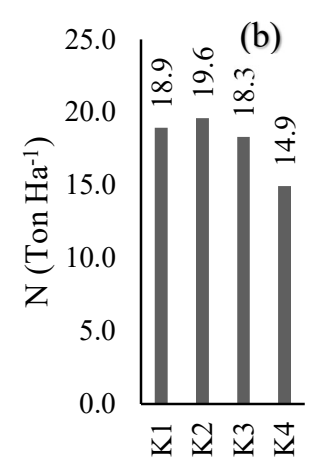

Kelerengan (\%)

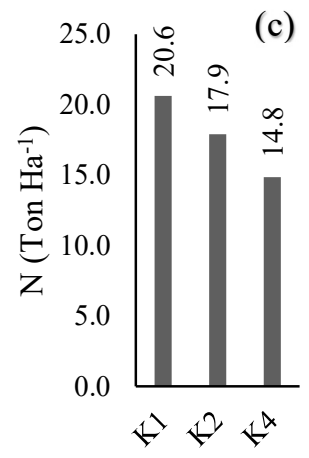

Kelerengan (\%)

Gambar 2. Cadangan N tanah pada berbagai penggunaan lahan : (a) kentang; (b) Apel; (c) Hutan di DAS mikro Kali Kungkuk, Kota Batu.

\section{Faktor yang mempengaruhi cadangan C dan N tanah di DAS mikro Kali Kungkuk}

Cadangan $\mathrm{C}$ dan $\mathrm{N}$ tanah dipengaruhi oleh sifat fisika tanah yaitu tekstur tanah (Gambar 3 dan 4). Tekstur merupakan perbandingan unsur pasir, debu dan liat sebagai penyusun tanah. Dalam hal ini pengukuran hubungan tekstur tanah difokuskan hanya pada fraksi liat yang merupakan situs aktif pertukaran hara dalam tanah. Menurut Hanafiah (2005) sebagian fraksi liat merupakan koloid aktif tanah sebagai situs pertukaran hara. Hasil uji korelasi menunjukkan bahwa $\mathrm{C}$ organik tanah dan $\mathrm{N}$ total tanah berkorelasi positif dengan fraksi liat $\left(r=0.58^{* *}\right.$ dan $\left.0.73^{* *}, \mathrm{p}<0.01\right)$ terutama pada lapisan atas 0-10 cm. Sebaliknya, C organik tanah dan N total tanah berkorelasi negatif dengan fraksi pasir $\left(\mathrm{r}=-0.50^{* *}\right.$ dan $\left.-0.55^{* *}, \mathrm{p}<0.01\right)$. Hal ini diduga karena liat mempunyai luas permukaan dan kemampuan menahan bahan organik dan hara yang lebih besar dibandingkan dengan fraksi pasir sehingga mengurangi kehilangan $C$ dan $\mathrm{N}$ melalui erosi maupun pencucian. Sebaliknya, apabila tanah didominasi oleh fraksi pasir, dapat menyebabkan kehilangan $\mathrm{C}$ organic dan $\mathrm{N}$ total tanah melalui pencucian ataupun runoff dan erosi karena tidak kuat di dalam mengikat unsur tersebut. Selain itu, Bot dan Banites (2005) menyatakan bahwa kerapatan ikatan antara permukaan partikel liat dan bahan organik dapat memperlambat proses dekomposisi sehingga bahan organik tanah tidak cepat hilang.

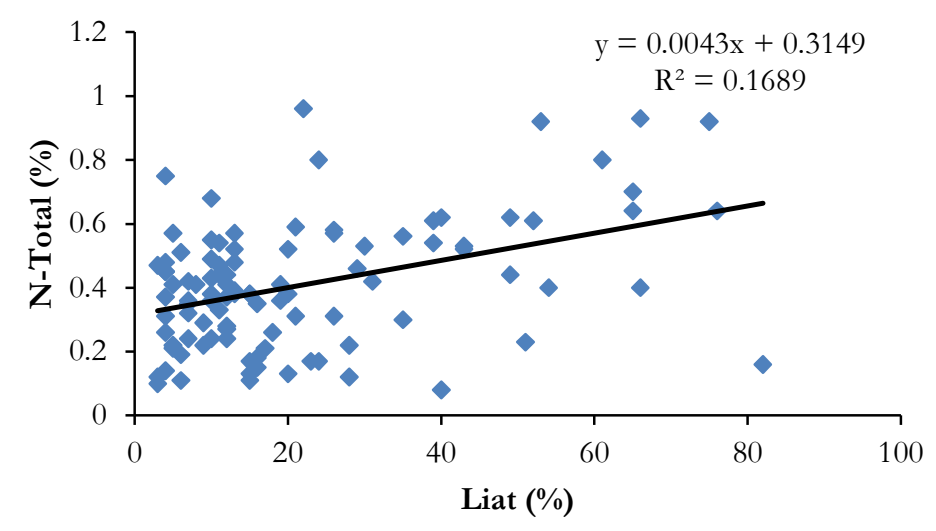

Gambar 3. Hubungan fraksi liat dengan N total tanah. 
Jurnal Tanah dan Sumberdaya Lahan Vol 8 No 1: 1-8, 2021

e-ISSN:2549-9793, doi: 10.21776/ub.jts1.2021.008.1.1

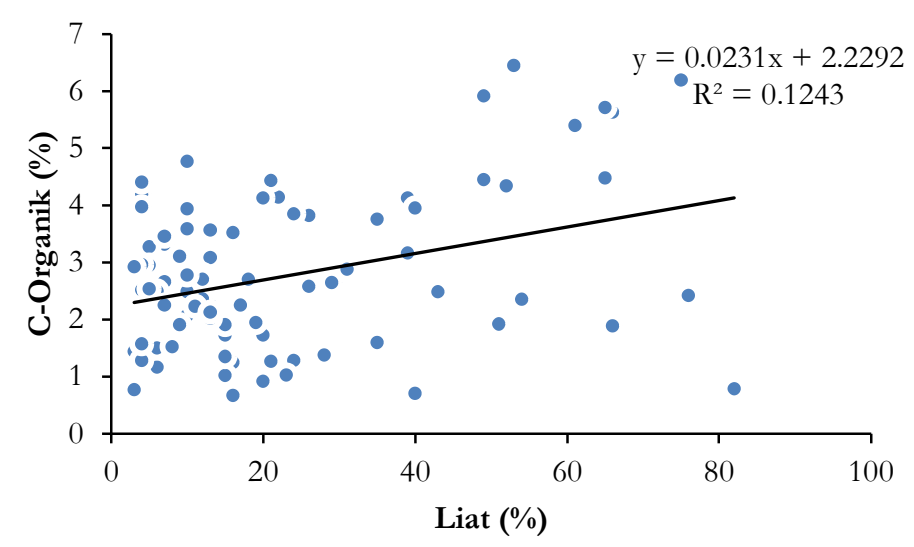

Gambar 4. Hubungan fraksi liat dengan C organik tanah.

\section{Pengaruh Corganik tanah terhadap sifat fisika tanah}

Berat volume atau berat isi tanah menggambarkan tingkat kepadatan tanah, dimana semakin padat tanah dapat mengakibatkan terganggunya pertumbuhan tanaman diatasnya. Haryati (2014) melaporkan bahwa rendahnya nilai berat isi tanah dapat mempermudah penetrasi akar ke dalam tanah sehingga hara-hara yang sulit tersedia akibat fiksasi menjadi lebih mudah dijangkau oleh rambut akar. Tingginya kandungan bahan organik tanah, direfleksikan dalam pengukuran C-organik tanah, diduga sebagai faktor yang berpengaruh terhadap bobot isi tanah. Agus $e t$ al. (2006) menyatakan bahwa tanah dengan kandungan bahan organik yang tinggi mempunyai berat isi yang relatif rendah. Hal ini sesuai dengan hasil uji korelasi pada penelitian ini yang menunjukkan bahwa $C$ organik tanah berkorelasi negatif dengan bobot isi tanah baik pada kedalaman $0-10,10-30$, dan $30-50 \mathrm{~cm}(\mathrm{r}=$ $-0.58^{* *},-0.55^{* *}$, dan $-0.40^{*} ; \mathrm{p}<0.01, \mathrm{p}<0.01$, $\mathrm{p}<0.05$; Gambar 5).

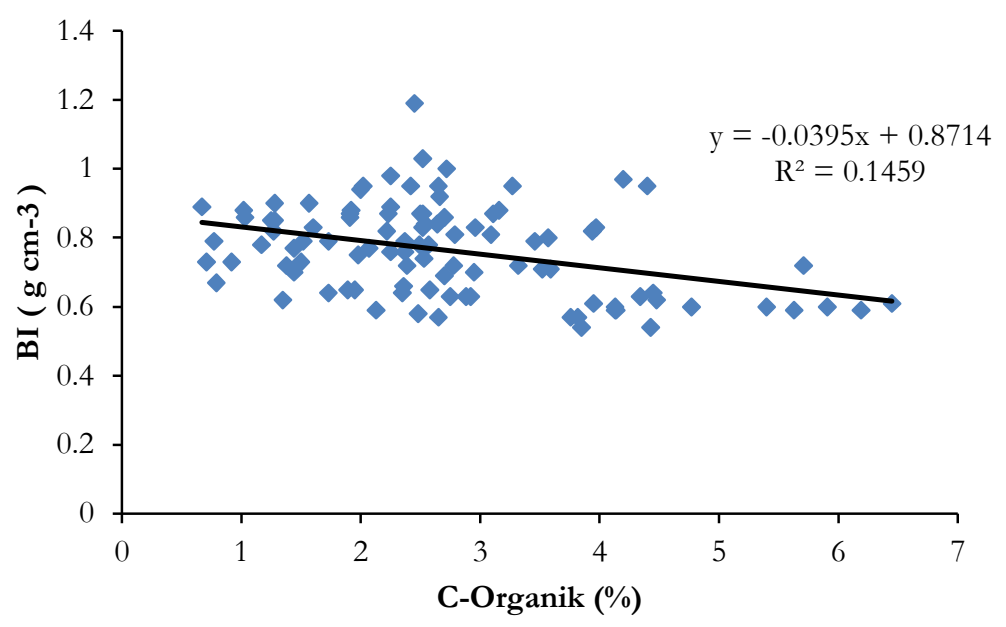

Gambar 5. Pengaruh C organik tanah terhadap bobot isi tanah pada berbagai penggunaan lahan dan kelerengan di DAS mikro Kali Kungkuk, Kota Batu. 


\section{Jurnal Tanah dan Sumberdaya Lahan Vol 8 No 1: 1-8, 2021 \\ e-ISSN:2549-9793, doi: 10.21776/ub.jts1.2021.008.1.1}

\section{Kesimpulan}

Perbedaan penggunaan lahan dan kelerengan berpengaruh terhadap konsentrasi dan cadangan C-organik dan N-total $(\mathrm{p}<0,05)$ baik pada kedalaman 0-10 cm, 10-30 cm, dan 30-50 $\mathrm{cm}$. Hutan dengan masukan seresah yang tinggi dan terus menerus, memiliki C-organik dan $\mathrm{N}$ total tanah yang lebih tinggi dibandingkan dengan kebun apel dan kentang. Selain itu, lahan dengan kelas kelerengan $0-8 \%$ dan $8-15 \%$ memiliki kandungan C-organik dan $\mathrm{N}$ total yang lebih tinggi dibandingkan lahan dengan kelas kelerengan $15-25 \%$ dan $>25 \%$. Cadangan Ptersedia lebih dipengaruhi perbedaan kelerengan saja dibanding perbedaan penggunaan lahan yang mana nilai cadangan P-tersedia paling baik berada pada lereng kelas $0-8 \%$ dan $8-15 \%$ dibandingkan kelas di atasnya.

\section{Ucapan Terima Kasih}

Penelitian ini sebagian didanai oleh hibah penelitian PNBP FP - UB tahun 2019. Penulis mengucapkan terimakasih kepada para pranata laboratorium pendidikan (PLP) di Jurusan Tanah Fakultas Pertanian Universitas Brawijaya. Selain itu, ucapan terima kasih juga ditujukan kepada para pengelola / pemilik lahan Tahura R. Soerjo atas bantuan pelaksanaan kegiatan penelitian ini.

\section{Daftar Pustaka}

Agus, F., R.D. Yustika, dan Umi H. 2006. Penetapan Berat Volume Tanah. Balai Besar Litbang Sumberdaya Lahan Pertanian. Departemen Pertanian. Bogor 25-34

Allen, K., Marife D. C., Kurniawan, S., Utami, S., R. andn Edzo, V. 2016. Spatial variability surpasses land-use change effects on soil biochemical properties of converted lowland landscapes in Sumatra, Indonesia. Geoderma 284 : 42-50

Baker, J,M., Ochsner, T.E., Venterea, R.T. and Griffis, T.J. 2006. Tillage and Soil Carbon Sequestration-What do we Really Know?. Collingwood:CSIRO Publishing.

Basic, F., Kisic, I., Mesic, M., Nestroy, O. and Butorac, A. 2004. Tillage and crop management affects on soil erosion in Central Croatia. Soil \& Tillage Research 78: 197-206
Bot, A. dan Benites, J. 2005. The Importance of Soil Organic Matter, Key to Drought-Resistant Soil and Sustained Food Production. Food and Agriculture Organization of the United Nations. Italia

BPS (Badan Pusat Statistik). 2018. Kecamatan Bumiaji Dalam Angka 2018. Badan Pusat Statistik. Batu

Direktorat Jenderal Rehabilitasi Lahan dan Perhutanan Sosial: Departemen Kehutanan. 2003. Rencana Teknik Lapangan Rehabilitasi Lahan dan Konservasi Tanah (RTL-RLKT).

Doetterl, S., Berhe, A.A., Nadeu, E., Wang, Z.G., Sommer, M., dan Fiener, P. 2016. Erosion, deposition and soil carbon: a review of processlevel controls, experimental tools and models to address $\mathrm{C}$ cycling in dynamic landscapes. EarthScience Reviews 154: 102-122

Hanafiah, A.H. 2005. Dasar-Dasar Ilmu Tanah. Rajawali Pers. Jakarta

Haryati, U. 2014. Karakteristik fisik tanah kawasan budidaya sayuran dataran tinggi, hubungannya dengan strategi pengelolaan lahan. Jurnal Sumberdaya Lahan 3(2) : 125-138

Kempen, B., Dalsgard, S., Kaaya, A.K., Chamuya, N., Gonzales, M.R., Pekkarinen, A. and Walsh, M.G. 2018. Mapping topsoil organic carbon concentrations and stocks for Tanzania. Geoderma 337: 164-180.

McKenzie, R. 2010. Soil Carbon Sequestration Under Pasture. (Project MCK 13538). In Australian McKenzie Soil Management. Orange NSW: Dairy Regions. Dairy Australia.

Nainggolan, G.D., Suwardi, dan Darmawan. 2009. Pola pelepasan nitrogen dari pupuk tersedia lambat (Slow Release Fertilizer) urea-zeolit-asam humat. Jurnal Zeolit Indonesia (8) 2: 89-96

Pawlson, D.S., Whitmore, A.P. and dan Goulding, K.W.T. 2011. Soil carbon sequestration to mitigate climate change-a critical re-examination to identify the true and the false. European Journal of Soil Science 62(1): 42-55.

Simbolon, S.D., Zulkifli, N., Abdul, R. D. and Delvian. 2016. Kerugian ekonomi sebagai dampak erosi di kawasan hulu DAS. Jurnal Ilmiah Ukhuwah. 3 (11) : 302-471.

Singh, P. dan Benbi, D.K. 2018. Soil organic carbon pool changes in relation to slope position and land-use in Indian Lower Himalayas. Catena 166: 171-180 